\title{
The Effect of the Great East Japan Earthquake on the Stock Prices of Non-life Insurance Companies
}

\author{
Atsushi Takao ${ }^{\mathrm{a}}$, Takuya Yoshizawa ${ }^{\mathrm{b}}$, Shuofen $\mathrm{Hsu}^{\mathrm{c}}$ and \\ Takashi Yamasaki ${ }^{\mathrm{a}}$ \\ ${ }^{a}$ Graduate School of Business Administration, Kobe University, 2-1 Rokkodai-cho, Nada-ku, Kobe, \\ Hyogo 657-8501, Japan. \\ E-mails: takao@kobe-u.ac.jp; yamasaki@kobe-u.ac.jp \\ ${ }^{\mathrm{b}}$ H.S. Insurance Co. Ltd., 3-12, Yotsuya, Shinjuku-ku, Tokyo 160-0004, Japan. \\ E-mail: takyok@nifty.com \\ ${ }^{\mathrm{c}}$ Department of Risk Management and Insurance, National Kaohsiung First University of Science and \\ Technology, No. 2, Juoyue Rd., Nantz District, Kaohsiung 811, Taiwan. \\ E-mail: shuofen@nkfust.edu.tw
}

The Great East Japan Earthquake of 11 March 2011 incurred huge damages for Japan. This paper investigates how this earthquake influenced the value of Japanese insurance companies, especially non-life insurance companies. Our findings are as follows. (1) The stock prices of insurance companies decreased right after the earthquake. The spread of this decrease was less for the stock prices of non-life insurance companies than for those of life insurance companies. (2) The more capital buffer a non-life insurance company had, the higher the stock return. (3) The Earthquake Insurance System on Dwelling Risks in Japan not only indemnifies seismic losses but also functions as a Japanese stock market stabiliser. The Geneva Papers (2013) 38, 449-468. doi:10.1057/gpp.2012.34

Keywords: insurance stock; catastrophe; stock market reaction; event study; Great East Japan Earthquake; Earthquake Insurance System on Dwelling Risks in Japan

Article submitted 25 November 2011; accepted 21 June 2012; published online 5 September 2012

\section{Introduction}

The Great East Japan Earthquake (GEJE) of 11 March 2011 incurred huge damages for Japan. The GEJE and the earthquake-triggered tsunami left over 15,000 people dead and over 100,000 houses in destruction. Furthermore, it caused a serious nuclear disaster at Fukushima.

Following the GEJE, the Japanese stock market fell precipitously. The closing price of the Nikkei 225 Index on 10 March was 10,434.38 yen. However, the Nikkei 225 took a nosedive immediately following the earthquake, at 2:46 p.m. and plummeted 179.95 yen, to a closing price of 10,254 yen on 11 March. ${ }^{1}$ The beginning of the following week, that is 14 March, when the nuclear accident had become a serious problem,

\footnotetext{
${ }^{1}$ Because the Japanese stock market closes at 3:00 p.m., this was only 14 minutes before the trading of the day ended. Nevertheless, it should be noted that Nikkei 225 fell precipitously in only 14 minutes.
} 
the Nikkei 225 Index plummeted 633.94 yen, to a closing price of 9,620.49 yen. Moreover, on 15 March, the closing price plunged another 1,015.34 yen, to 8,605.15 yen. The decline on 15 March was the third largest since World War II, after that of Black Monday in 1987 and that of the Global Financial Crisis in 2008.

According to the stock price index by industry, on 11 March, the insurance stock index declined the most, that is, -1.65 per cent, due to concerns about the increasing number of insurance claims caused by the earthquake. AIR Worldwide, a U.S. catastrophe modelling firm, published estimates on 13 March that the insured property losses from the GEJE ranged between $\$ 14.5$ billion and $\$ 34.6$ billion. ${ }^{2}$ With regard to the total amounts of insurance claims from earthquake peril, losses from the GEJE were predicted to be the largest ever recorded. As stated by the Reuters news agency ${ }^{3}$ on $13 \mathrm{March}$, it is possible that the loss is equivalent to the total amount of insurance claims from disasters throughout the world in 2010 and exceeds the largest amount of insurance claims for an earthquake event so far, that from the Northridge earthquake, which struck Los Angeles in 1994.

On the other hand, Japanese non-life insurance companies forecasted that the claims for Earthquake Insurance on Dwelling Risks from the GEJE will amount to 1 trillion yen, exceeding the total insured property losses of 78.3 billion yen from the Great Hanshin-Awaji Earthquake of 1995 and thus becoming the highest in Japanese history. Earthquake Insurance on Dwelling Risks, which covers 30-50 per cent of the amount of household fire insurance policy as an earthquake rider (see the section "Overview of the Earthquake Insurance on Dwelling Risks in Japan"), has reinsurance support from the Japanese government, and the Japanese government and the non-life insurance industry have together set aside a total reserve of 2.3 trillion yen to accommodate claim payments. In addition, the government also directs the Special Accounts for Earthquake Damages Reinsurance fund to deal with claims. Hisahito Suzuki, chairman of the General Insurance Association of Japan (GIAJ), announced at a press conference on 17 March 2011 that with the government reinsurance protection, the massive payments may not have a serious impact on individual non-life insurance companies that had accumulated sufficient reserves.

However, since many plants suffered damages, payments of earthquake insurance on commercial risks increased. In addition, unrealised stockholding value decreased due to the drop in the stock market. This is because securities (national government bonds, local government bonds, corporate bonds, domestic stocks, foreign securities and other securities) comprise about 70 per cent of total assets in non-life insurance companies, of which domestic stocks comprise as much as 20 per cent, according to GIAJ. The GEJE caused a series of downward revisions in the earnings of Japanese non-life insurance companies for the fiscal year ending 31 March 2011. For example, on 2 May 2011, NKSJ Holdings announced downward revisions in their ordinary and current net income for the year, from a surplus of 48 billion yen and 25 billion yen, respectively, to a deficit of 6.4 billion yen and 12.9 billion yen, respectively. On the same day, MS\&AD Insurance

\footnotetext{
${ }^{2}$ The figures are based on a range from 1.2 trillion yen to 2.8 trillion yen, converted at the exchange rate of 1 U.S. dollar equals 81.85 yen at that time.

${ }^{3}$ Reuters News Agency (2011).
} 
Group announced downward revisions in their ordinary and current net income for the year, from a surplus of 71 billion yen and 40 billion yen, respectively, down to 21 billion yen and 5 billion yen, respectively. On 6 May, Tokio Marine Holdings ${ }^{4}$ revised its annual predictions of ordinary and current net income from surpluses of 180 billion yen and 115 billion yen, respectively, down to 126 billion yen and 71 billion yen, respectively. Moreover, the impact of the earthquake profoundly influenced not only Japanese nonlife insurance companies but also foreign reinsurance companies. It is likely that the four major European reinsurance companies Munich Re, Swiss Re, Hannover Re and SCOR will pay a total of about 332 billion yen to non-life insurance companies for this earthquake, or 180 billion yen, 100 billion yen, 30 billion yen and 22 billion yen, respectively. For this reason, reinsurance rates increased following the GEJE.

An extensive literature explores the effects of catastrophes on the firm value of insurance companies; however, the empirical results, reviewed further in this paper, are mixed. This paper analyses the impact of the GEJE on Japanese non-life insurance companies, especially under the specific system design of risk pooling regarding earthquakes and determines which of the two opposing hypotheses proposed applies to the Japanese insurance market. The goals of this paper are (1) to measure the market reaction of Japanese non-life insurance companies following the GEJE, (2) to examine whether the degree of capital surplus of insurers affects the value of non-life insurance stocks, and (3) to assess the validity of the Earthquake Insurance System on Dwelling Risks in Japan by comparing the market reactions of life insurance companies.

The remainder of this paper is organised as follows: the next section describes the GEJE in detail, followed by a section reviewing previous studies. The section "Overview of the Earthquake Insurance on Dwelling Risks in Japan" describes the Earthquake Insurance System on Dwelling Risks, especially its system design in Japan. The "Data and methodology" section develops the hypotheses and discusses the sample data and methodology. The penultimate section presents the empirical results and then we draw our conclusions. Two appendices are also provided for the robustness check and for validating if investors are rational in responding to major catastrophes.

\section{Background of GEJE}

The earthquake occurred at 2:46 p.m. on 11 March 2011. Its epicentre was off the coast of Sanriku (130 km east by southeast off the Oga Peninsula) and it had a magnitude of 9.0, the most powerful in the observation history in Japan and the fourth most powerful ever recorded in the world since 1900. Japan Meteorological Agency formally named this earthquake the "2011 off the Pacific coast of Tohoku Earthquake".

An aftershock of magnitude 7 occurred in Kurihara, in the Miyagi Prefecture. Aftershocks of intensity greater than 6 were also recorded in 28 other communities in the Miyagi, Fukushima, Ibaragi and Tochigi Prefectures. Aftershocks of magnitude less than 6 were recorded from the Hokkaido District to the Kyushu area, away from the Tohoku area. Furthermore, an earthquake-triggered tsunami hit the Pacific coast

\footnotetext{
${ }^{4}$ Tokio Marine Group, MS \& AD Insurance Group and NKSJ Group are the three largest non-life insurance groups in Japan as of 2011.
} 
from Hokkaido to Okinawa, reaching a height exceeding 40 meters in the Tohoku area. A round-robin cabinet of the Japanese government on 1 April 2011 formally named this catastrophe the "Great East Japan Earthquake" (hereafter GEJE).

The GEJE and tsunami was catastrophic for Japan. It left 15,790 people dead9,462 in the Miyagi Prefecture, 4,659 in the Iwate Prefecture and 1,603 in the Fukushima Prefecture - and 4,056 missing. Damage to buildings was also widespread, with 115,262 houses experiencing complete destruction and 163,306 experiencing partial destruction.

Furthermore, following the GEJE, the destruction of four out of six reactors at Fukushima Daiichi Nuclear Power Plant (FDNPP) run by Tokyo Electric Power Company and the leakage of radioactive materials worsened the situation. On 12 March, evacuation instructions were issued to the inhabitants within a $20 \mathrm{~km}$ radius of FDNPP. On 18 March, the Japan Nuclear and Industrial Safety Agency tentatively announced that the accidents of reactors No.1, No.2 and No.3 were considered level 5 according to the International Nuclear Event Scale (INES), which ranges from 1 to 7 with the most serious being a 7 referred to as a "major accident", while a 1 is an "anomaly". Level 5 is referred to as an "accident with wider consequences" like the Three Mile Island Event in 1979. The scale is designed so the severity of an event is about ten times greater for each increase in level. ${ }^{5} \mathrm{On} 25 \mathrm{March}$, an evacuation request was issued to the inhabitants within a $20-30 \mathrm{~km}$ radius of FDNPP. On 12 April, the level was raised to 7, the worst level. Since the 1986 Chernobyl accident in the Soviet Union, no other nuclear accident besides Fukushima has rated a 7. It has been reported that the damage from this nuclear accident has affected the water supply, farm products, seawater and soil of Japan as well as in foreign countries where radioactive materials have also been detected. The final situation of the Fukushima nuclear accident is not yet known due to unforeseen circumstances in the future.

\section{Literature review}

Since the 1990s, there has been considerable research concerning the effect of catastrophes on the firm value of insurance companies. Shelor et al. ${ }^{6}$ find that the average abnormal stock returns of property-liability insurers were significantly positive following the Loma Prieta earthquake that struck California in 1989. On the basis of their results, the authors argue that insurers benefit from a catastrophic event because of subsequent increased demand (gaining from loss hypothesis) in that the investor expectations of higher demand for insurance and higher premiums will cause insurance stock prices to increase at the time of the disaster (the positive effect) or at the very

\footnotetext{
${ }^{5}$ INES is a tool for promptly communicating to the public in consistent terms the safety significance of reported nuclear and radiological incidents and accidents, excluding naturally occurring phenomena such as radon. The scale can be applied to any event associated with nuclear facilities, as well as the transport, storage and use of radioactive material and radiation sources. The primary purpose of the INES scale is to facilitate communication and understanding between the technical community, the media and the public on the safety significance of events. The aim is to keep the public, as well as nuclear authorities, accurately informed on the occurrence and potential consequences of reported events.

${ }^{6}$ Shelor et al. (1992).
} 
least to partially offset the negative effect of the potential losses due to the earthquake. Employing a different approach, Aiuppa et al. ${ }^{7}$ also find similar results, with the Loma Prieta earthquake having had a positive impact on the stock returns of non-life insurance companies.

Aiuppa and Krueger ${ }^{8}$ and Lamb and Kennedy ${ }^{9}$ both investigate the impact of the 1994 Northridge earthquake in Los Angeles on the firm value of insurance companies. Lamb and Kennedy ${ }^{9}$ find that property-liability insurers experienced a significant positive reaction immediately after the Northridge earthquake. Aiuppa and Krueger, ${ }^{8}$ on the other hand, indicate that earthquake-exposed firms sustained their value and non-earthquake-exposed insurers declined in value immediately after the Northridge earthquake.

Contrary to the positive impact of catastrophes on insurance firm value, Lamb ${ }^{10}$ finds that the 1992 Hurricane Andrew in South Florida and Louisiana had a significant negative impact on the stock returns of hurricane-exposed insurers. Likewise, Cagle $^{11}$ investigates the 1989 Hurricane Hugo in South Carolina and finds similar results, with the hurricane having had a negative impact on the stock returns of exposed insurers. Moreover, Yamori and Kobayashi ${ }^{12}$ investigate the stock market reactions of Japanese property-liability insurers following the 1995 Great HanshinAwaji Earthquake and find significantly negative abnormal returns.

Cummins and Lewis ${ }^{13}$ demonstrate that all property-casualty insurers experienced strong negative returns in the immediate aftermath of the World Trade Center (WTC) attacks. Furthermore, they also find that the stock prices of insurers with strong financial ratings rebounded after the first post-attack week, while those of weaker insurers did not.

It is evident from the literature that catastrophic events have both favourable and unfavourable effects on the firm value of insurance companies. Chen et al. ${ }^{14}$ investigate the effects of the WTC attack on the insurance industry and define shortand long-term effects as follows. The short-term claim effect is a reduction in firm value resulting from insufficient ex ante premium for catastrophic losses. The longterm effect is an increase in firm value resulting from the increase in ex post demand for insurance. The authors find that firm type (property-liability vs. non-propertyliability insurers), the amount of the estimated losses, the firm's tax position and the extent of reinsurance usage are important determinants of the short-run effect. On the other hand, firm type, losses, financial strength, underwriting risk ${ }^{15}$ and reinsurance usage are of great significance in deciding the long-run position.

${ }^{7}$ Aiuppa et al. (1993).

${ }^{8}$ Aiuppa and Krueger (1995).

${ }^{9}$ Lamb and Kennedy (1997).

${ }^{10}$ Lamb (1995).

11 Cagle (1996).

${ }^{12}$ Yamori and Kobayashi (2002).

${ }^{13}$ Cummins and Lewis (2003).

${ }^{14}$ Chen et al. (2008).

${ }^{15}$ Following Lamm-Tennant and Starks (1993), Chen et al. (2008) define underwriting risk as the standard deviation of the loss ratios. 


\section{Overview of the Earthquake Insurance on Dwelling Risks in Japan}

As has been stipulated in insurance contracts, household fire insurance in Japan covers losses caused by fire, lightning, typhoons, flooding and so forth but does not cover losses due to earthquakes, volcano eruptions or tsunamis, such as that caused by the GEJE. To cover the perils of earthquakes and tsunamis, policyholders must purchase Earthquake Insurance on Dwelling Risks.

Earthquake Insurance on Dwelling Risks in Japan was introduced after the Niigata earthquake in 1964. However, it cannot be purchased alone but only as a rider to a fire insurance contract. Policyholders can decide to add the earthquake rider at any time during the contract period. The coverage includes buildings for residence and/or movable properties for living (chattels), but excludes properties not used as dwellings, such as factories and office buildings. The amount insured should be set within 30-50 per cent of that in the fire insurance contract. The upper limits of the amount insured are 50 million yen and 10 million yen for buildings and chattels, respectively. On the other hand, the claims are paid according to the degree of damage - that is, total, half or partial loss of the insured object - as determined by a professional investigator. The amounts paid are 100 per cent, 50 per cent and 5 per cent of the amount insured for total loss, half loss and partial loss, respectively. However, total insurance claim payments are limited to 5.5 trillion yen per event. Thus, if the damage of an event exceeds this limit, the payments of the insurance claims for each policyholder are reduced proportionally.

The premium rate is uniformly set for all insurance companies and divided into several risk classifications according to the structure and location of the insured building or the building where the insured chattels are held. In addition, a discount rate system applies to seismic resistant structures.

On the basis of the laws concerning earthquake insurance, Japan Earthquake Reinsurance (JER), ${ }^{16}$ Japanese non-life insurance companies and the government shared insurance liabilities through a three-layer reinsurance scheme, as follows (as of the end of March 2011): the first layer had a total payment limit of 115 billion yen, which was fully assumed by JER. The second layer covered payments from 115 billion yen to 1,925 billion yen, which was equally shared by the non-life insurance companies (including JER) and the government. The third layer covered payments from 1,925 billion yen to 5.5 trillion yen, 95 per cent of which was paid by the government and the remaining 5 per cent of which was borne by the non-life insurance companies, including JER (Figure 1).

Non-life direct insurance companies cede all insurance risks of Earthquake Insurance on Dwelling Risks by reinsurance to JER, who homogenises the reinsured risks and then cedes them proportionally by retrocession to the non-life direct insurance companies (including Toa Reinsurance Co.) and the government. JER takes up those indemnity liabilities that are left un-reinsured.

\footnotetext{
16 JER was founded in 1966 as the only company in Japan permitted to exclusively handle reinsurance for Earthquake Insurance on Dwelling Risks.
} 


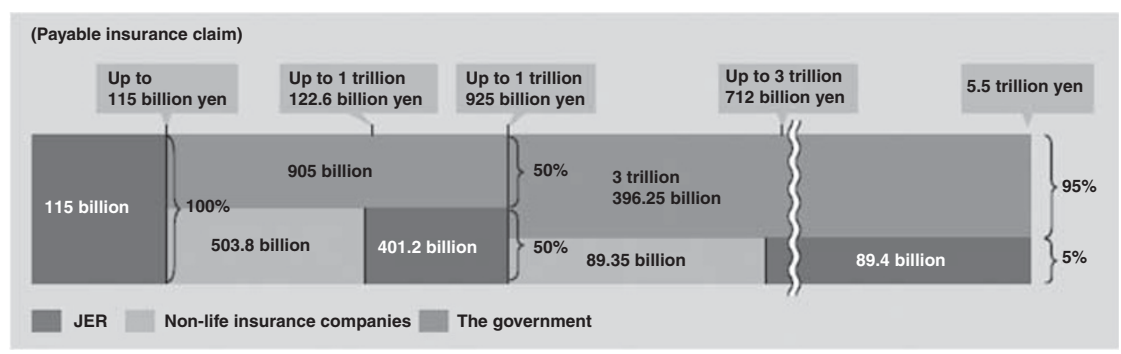

Figure 1. Earthquake insurance on dwelling risks scheme in Japan as of March 2011. Source: JER ${ }^{17}$, p. 12.

Regarding the expected total payments of 1.2 trillion yen projected for the GEJE, for example, JER carries 153.7 billion yen alone, the non-life insurance companies, including Toa Reinsurance Co., carry 503.8 billion yen and the government carries 542.5 billion yen (Figure 2).

Since the Great Hanshin-Awaji Earthquake of 1995, the proportion of the number of household policies with Earthquake Insurance on Dwelling Risks with respect to the number of households in Japan has been increasing, reaching 23.0 per cent by the end of March 2010, up from 9.0 per cent at the end of March 1995. The proportion of the number of household fire insurance policies with Earthquake Insurance on Dwelling Risks with respect to the number of all household fire insurance policies was 46.5 per cent at the end of March 2010, up from 33.3 per cent at the end of March 2002. In the Miyagi Prefecture, where people suffered the greatest earthquake damage this time, these two percentages were 32.5 per cent and 66.9 per cent, respectively. ${ }^{17}$

\section{Data and methodology}

\section{Hypothesis}

As described previously, the impact of a catastrophic event on the stock performance of insurance companies is inconclusive. This paper employs a discounted cash flow approach to examine the effects of the GEJE on the firm value of non-life insurance companies under the Japanese earthquake insurance system's peculiar risk-pooling design. Specifically, the value of stock insurer $i$ can be defined as

$$
\begin{aligned}
V_{i} & =\frac{E\left(N C F_{i, 1}\right)}{\left(1+\rho_{i}\right)}+\frac{E\left(N C F_{i, 2}\right)}{\left(1+\rho_{i}\right)^{2}}+\frac{E\left(N C F_{i, 3}\right)}{\left(1+\rho_{i}\right)^{3}}+\cdots \\
& =\sum_{t=1}^{\infty} \frac{E\left(N C F_{i, t}\right)}{\left(1+\rho_{i}\right)^{t}}
\end{aligned}
$$

\footnotetext{
${ }^{17}$ For Earthquake Insurance on Dwelling Risks in Japan, see JER (2010).
} 


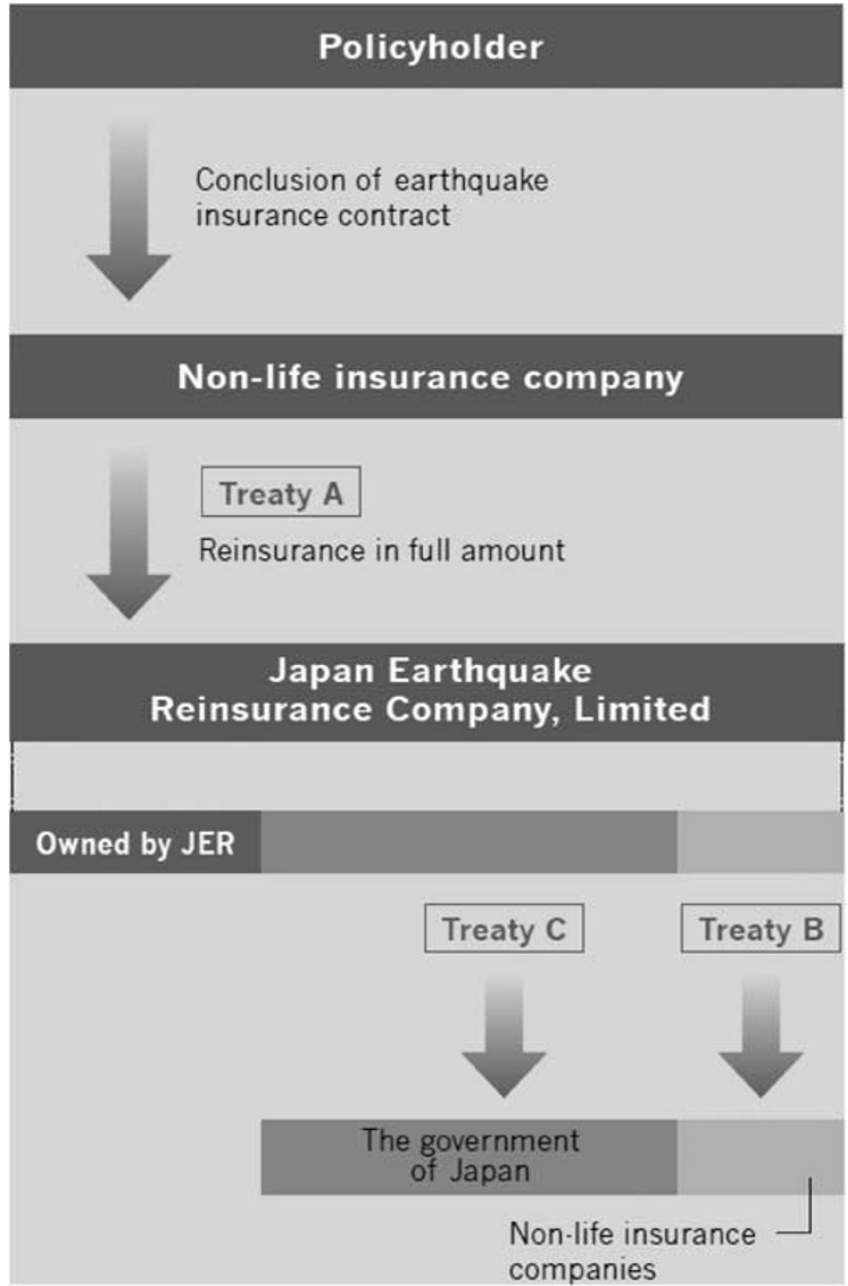

Figure 2. Earthquake Insurance on Dwelling Risks transaction flowchart. Source: JER ${ }^{17}$, p. 11 .

where $E\left(N C F_{i, t}\right)$ is the expected net cash flow for insurer $i$ in period $t$ and $\rho_{i}$ is the cost of capital for insurer $i$.

If insurers do not anticipate a catastrophic event, unexpectedly large insurance claims can result in higher expenses for insurers and reduce firm value. On the other hand, it is possible that a catastrophic event can increase demand for insurance coverage. If a catastrophic event causes increases in both insurance demand and the premium rate, insurers will increase long-run profitability. If increased long-run profitability exceeds firm value decreased by short-run claim payments, insurers' stock prices will rise following a catastrophic event because of the expectation that prices will rise. 
However, because insurance premiums for Earthquake Insurance on Dwelling Risks are regulated by the government at the non-loss and non-profit level, insurers are not free to determine them in Japan. Furthermore, even if the participation rate in Earthquake Insurance on Dwelling Risks increased, the funds raised from there must be held without investment and shareholders do not have a right to them. Therefore, insurers' future earnings available for dividends will not be affected directly by Earthquake Insurance on Dwelling Risks and the firm value based on Eq. (1) will not be affected either.

However, as described in the previous section, because Earthquake Insurance on Dwelling Risks cannot be purchased alone but only as a rider to a fire insurance contract, it is possible that the increase in demand for fire insurance coverage is associated with an increase in demand for earthquake insurance coverage.

Japanese direct non-life insurers have been paying numerous claims for the GEJE. However, as described in the section "Overview of the Earthquake Insurance on Dwelling Risks in Japan", the Earthquake Insurance System on Dwelling Risks in Japan limits the amounts of payable insurance claims. In addition, direct non-life insurers excluding JER and the government share a portion of insurance claims over 115 billion yen, which is retained by JER up to 1.1226 billion yen (see Figure 1). Furthermore, Japanese direct non-life insurers saved 524.3 billion yen as earthquake insurance risk reserves for the possible payment for Earthquake Insurance on Dwelling Risks claims. In addition, Japanese non-life insurers are fully buffered to pay the insurance claims for a catastrophe using total catastrophe loss reserves, which were about 936 billion yen, 833 billion yen and 633 billion yen for Tokio Marine Holdings, MS\&AD Insurance Group and NKSJ Holdings, respectively, at the end of March $2010 .^{18}$ As a result, there is little chance the earthquake will cause Japanese non-life insurers to become insolvent.

In this earthquake, the key factors affecting non-life insurers' performance are the following:

\section{Deteriorations in earnings}

(a) Loss on valuation of exiting assets

(b) Net insurance payments for earthquake insurance on commercial risks

(c) Net insurance payments for Earthquake Insurance on Dwelling Risks

(d) Net insurance payments for earthquake insurance on personal risks other than Earthquake Insurance on Dwelling Risks

(e) Decrease in future premium income, due to total loss or being carried away in a tsunami, of insured subjects

(f) Net insurance payments by life subsidiaries

(g) Decrease in earnings due to an increase in the reinsurance premium rate

${ }^{18}$ The total catastrophe loss reserves for each insurance group are calculated as the sum of the figures for Tokio Marine \& Nichido Fire, Nisshin Fire and E. design Insurance for Tokio Marine Group; Mitsui Sumitomo Insurance, Aioi, Nissei Dowa and Mitsui Direct for MS\&AD Insurance Group; and Sompo Japan, Nipponkoa, Sonpo 24 and Saison Automobile \& Fire Insurance for NKSJ Group, respectively. We obtained this data from The Statistics of Japanese Non-life Insurance Business 2010 published by the Insurance Research Institute. 
2. Improvements in earnings

(h) Increase in demand for fire insurance coverage associated with increase in demand for earthquake coverage

As for life insurers, the Life Insurance Association of Japan (LIAJ) announced on 15 March 2011 that the payments of accident-related coverage by GEJE would be fully paid, regardless of the exemption clause stated in the insurance policy, which permitted life insurers to reduce or refuse to pay insurance claims related to seismic hazards. On 19 July 2011, the Financial Services Agency stated that total life insurance claims were 200 billion yen.

On the other hand, as for non-life insurers, the claims for the Earthquake Insurance on Dwelling Risks accounting for 1.2 trillion yen would be reimbursed by JER and the government as stated in the previous section, and the net burden of direct non-life insurers was fully covered by their earthquake insurance risk reserves as stated in the previous section. Furthermore, remaining claims other than the Earthquake Insurance on Dwelling Risks were expected to be reimbursed by reinsurers and, for the five largest Japanese non-life insurers, which belonged to the three biggest non-life insurance groups, the defrayments without Earthquake Insurance on Dwelling Risks were only 200 billion yen after receiving reinsurance claims. ${ }^{19}$

Therefore, the impacts of net insurance payments on non-life insurance companies were almost the same as the one on life insurance companies, owing to the government reinsurance system of the Earthquake Insurance on Dwelling Risks and commercial reinsurance by reinsurance companies for other earthquake insurance covers.

On the other hand, within our event period (11 March 4 April 2011), both LIAJ and GIAJ did not state the estimation of each total insurance claims. For investors, however, it was difficult to expect the total life insurance claims within our event period, while it was relatively easy to expect the net non-life insurance claims after receiving reinsurance claims for Earthquake Insurance on Dwelling Risks because non-life insurance companies were limited to pay up to 503.8 billion yen (see Figure 1), which was fully covered by earthquake insurance risk reserves. Therefore we hypothesize the following.

H1: The reaction of non-life insurers' stock prices is less than that of life insurers' following the GEJE because of Earthquake Insurance on Dwelling Risks in Japan.

Previous literature shows that a large catastrophic event leads to "flight to quality" within insurance markets. The causes of this flight to quality can be considered from several aspects: (1) A catastrophic event is expected to deplete the net internal capital of many insurers and reinsurers, resulting in price increases and supply restrictions, ${ }^{20}$ and (2) a large catastrophic loss can create new incentives for primary insurers and

\footnotetext{
19 According to the Financial Services Agency's press release on 19 July 2011

${ }^{20}$ Froot and O'Connell (1999).
} 
Table 1 Japanese insurance companies in our sample

\begin{tabular}{lll}
\hline Name & Form & Listing exchange \\
\hline Tokio Marine Holdings & Non-life insurance holding company & TSE 1st \\
MS\&AD Insurance Group & Non-life insurance holding company & TSE 1st \\
NKSJ Holdings & Non-life insurance holding company & TSE 1st \\
Dai-Ichi Life & Life insurance company & TSE 1st \\
T\&D Holdings & Life insurance holding company & TSE 1st \\
\hline
\end{tabular}

reinsurers to break their relational contracts. ${ }^{21}$ Cummins and Lewis ${ }^{13}$ show that the stock prices of insurers with strong financial ratings rebounded the first week after the WTC attacks, while those of insurers with weaker ratings did not. As such, we hypothesize the following.

H2: The market returns of individual non-life insurers following the GEJE are relatively higher for non-life insurers with strong financial grounds.

Data

To test the market reactions to the GEJE, we examine the stock returns of Japanese non-life insurance companies traded on the Tokyo Stock Exchange (TSE). On 31 March 2011, four non-life insurance companies-MS\&AD Insurance Group, Tokio Marine Holdings, NKSJ Holdings, and Fuji Fire and Marine-were listed in the first section of the TSE. However, we exclude Fuji Fire and Marine because it was undergoing an M\&A. ${ }^{22}$ In addition, we include two TSE-listed life insurance companiesDai-ichi Life and T\&D Holdings - for comparison purposes. The insurers in our sample are shown in Table 1.

\section{Methodology}

To examine the proposed hypotheses, we conduct an event study analysis to assess the market reaction to insurer stocks following the GEJE. Following Cummins and Lewis, ${ }^{13}$ we adopt a standard market model event study methodology where the returns of the underlying securities are assumed to be jointly multivariate normal and independently and identically distributed through time. The analysis involves calculating the returns for each of the insurers in our sample using data from the Nikkei NEEDS

\footnotetext{
${ }^{21}$ Lewis and Murdock (1996).

${ }^{22}$ Chartis, a wholly owned subsidiary of AIG, announced a cash tender offer through its wholly owned subsidiary Chartis Japan for all common shares and stock acquisition rights of Fuji. Because the tender offer was scheduled to commence on 14 February 2011 and to run until 24 March 2011, we removed Fuji from our sample.
} 
Financial Quest. Using this approach, the expected return for any given insurer can be defined as

$$
R_{i t}=a_{i}+\beta_{i} R_{m t}+e_{i t}
$$

where $R_{i t}$ is the actual dividend-adjusted return on insurer $i$ on day $t, R_{m t}$ is the Tokyo Stock Price Index (TOPIX) return on day $t, \alpha_{i}$ is the idiosyncratic return on insurer $i, \beta_{i}$ is the beta coefficient of insurer $i$ and $e_{i t}$ is the error term of the regression.

The estimation period is 200 trading days, dating back from the day before the GEJE. Using the estimated $\hat{\alpha}_{i}$ and $\hat{\beta}_{i}$, the abnormal return $(A R)$ of our sample for the event window is calculated as

$$
A R_{i \tau}=R_{i \tau}-\left(\hat{a}_{i}+\hat{\beta}_{i} R_{m \tau}\right)
$$

The event period comprises 15 trading days following the GEJE, that is, from 11 March 2011 to 4 April 2011.

We examine the market reactions of our sample that belong to the same industry (insurance sector) with the same event day (11 March 2011). We adjust the estimated variance in returns by the contemporaneous cross-sectional variance of the sample, which applies the standardised cross-sectional procedure developed by Boehmer et al. ${ }^{23}$

For any given insurer, we can compute the standardised abnormal returns (SAR) as

$$
S A R_{i \tau}=\frac{A R_{i \tau}}{\hat{s}_{i} \sqrt{1+\frac{1}{T}+\frac{\left(R_{m \tau}-\bar{R}_{m}\right)^{2}}{\sum_{t=1}^{T}\left(R_{m t}-\bar{R}_{m}\right)^{2}}}}
$$

where $A R_{i \tau}$ is the abnormal return on insurer $i$ on event day $\tau, \hat{s}_{I}$ is the standard error of the abnormal return for insurer $i$ from the market model regression, $T$ is the number of days in the estimation period, $R_{m \tau}$ is the TOPIX return on $\tau$ and $R_{m}$ is the average of TOPIX returns in the estimation period. Using $S A R_{i \tau}$, we further compute the $z$-statistics as

$$
z=\frac{\frac{1}{n} \sum_{i=1}^{n} S A R_{i \tau}}{\sqrt{\frac{1}{n(n-1)} \sum_{i=1}^{n}\left(S A R_{i \tau}-\frac{1}{n} \sum_{i=1}^{n} S A R_{i \tau}\right)^{2}}}
$$

where $n$ is the number of observations in the sample.

\footnotetext{
${ }^{23}$ Boehmer et al. (1991).
} 
Atsushi Takao et al

The Effect of the Great East Japan Earthquake

Table 2 Daily average abnormal returns for non-life or life insurance companies following the GEJE

\begin{tabular}{|c|c|c|c|c|c|}
\hline \multirow[t]{2}{*}{$t$} & \multirow[t]{2}{*}{ Date } & \multicolumn{2}{|c|}{$\begin{array}{l}\text { Non-life insurance company } \\
\qquad(N=3)\end{array}$} & \multicolumn{2}{|c|}{$\begin{array}{l}\text { Life insurance company } \\
\qquad(N=2)\end{array}$} \\
\hline & & $\begin{array}{l}\text { Average abnormal } \\
\text { returns }(\%)\end{array}$ & z-value & $\begin{array}{l}\text { Average abnormal } \\
\text { returns }(\%)\end{array}$ & $z$-value \\
\hline 0 & 11 March 2011 & -0.60 & $-1.793^{*}$ & 1.08 & $3.522 * * *$ \\
\hline 1 & 14 March 2011 & -2.40 & $-1.904 *$ & -5.52 & -1.641 \\
\hline 2 & 15 March 2011 & 6.27 & $2.908 * * *$ & 11.11 & $14.017 * * *$ \\
\hline 3 & 16 March 2011 & -4.11 & $-6.662 * * *$ & -4.56 & $-2.805^{* * *}$ \\
\hline 4 & 17 March 2011 & -1.92 & $-2.866 * * *$ & -0.15 & -0.245 \\
\hline 5 & 18 March 2011 & -2.44 & $-14.755^{* * *}$ & 0.65 & 0.086 \\
\hline 6 & 22 March 2011 & 0.56 & 0.802 & -3.61 & $-1.918^{*}$ \\
\hline 7 & 23 March 2011 & 1.27 & $2.190 * *$ & 1.83 & $9.705 * * *$ \\
\hline 8 & 24 March 2011 & -0.30 & -0.398 & -2.67 & $-1.977 * *$ \\
\hline 9 & 25 March 2011 & 0.63 & 0.470 & -2.98 & $-4.654 * * *$ \\
\hline 10 & 28 March 2011 & 0.68 & 1.378 & -1.74 & $-3.586^{* * *}$ \\
\hline 11 & 29 March 2011 & 1.69 & 1.244 & -0.09 & 0.052 \\
\hline 12 & 30 March 2011 & -1.77 & $-2.362 * *$ & -0.15 & -0.202 \\
\hline 13 & 31 March 2011 & 0.14 & 0.428 & 2.62 & $2.811 * * *$ \\
\hline 14 & 1 April 2011 & -0.05 & -0.207 & -1.47 & $-10.098 * * *$ \\
\hline 15 & 4 April 2011 & 1.43 & 1.028 & 0.34 & 0.598 \\
\hline $\operatorname{CAR}(0,4)$ & & -2.77 & $-11.671 * * *$ & 1.96 & $19.888 * * *$ \\
\hline $\operatorname{CAR}(5,15)$ & & 1.83 & $2.338 * *$ & -7.27 & $-8.611 * * *$ \\
\hline $\operatorname{CAR}(0,15)$ & & -0.94 & -1.387 & -5.31 & $-5.590 * * *$ \\
\hline
\end{tabular}

Note: The superscripts $* * *$ and $* * *$ represent statistical significance at the 10 per cent, 5 per cent and 1 per cent levels, respectively.

\section{Results}

The results of our analysis are shown in Table 2 and Figure 3. From Figure 3, it is apparent that the abnormal returns of all insurance companies were strongly negative on 14 March 2011, that is the beginning of the subsequent week following the GEJE, but rebounded on 15 March. On 4 April, Dai-ichi Life had the lowest Cumulative Abnormal Returns (CARs), with -6.93 per cent, followed by T\&D Holdings, Tokio Marine Holdings, NKSJ Holdings and MS\&AD Insurance Group with -3.84 per cent, -1.75 per cent, -1.43 per cent and 0.43 per cent, respectively.

Table 2 compares the average abnormal returns of the three non-life insurers and two life insurers. The CARs in the first week of the GEJE ( $t=0$ to 4 ) are -2.77 per cent $(z=-11.671)$ for non-life insurers and 1.96 per cent $(z=19.888)$ for life insurers.

In sum, we find that the stock prices of non-life insurers drop much more significantly than those of life insurers following the first week of the GEJE. However, it is possible that the CARs of that week included strong noise because of the relatively short window, so there is a great deal of uncertainty in estimating the total amount of insurance claims. The GIAJ announced that non-life insurance companies were not expected to pay the approximately 1 trillion yen for earthquake insurance claims until 


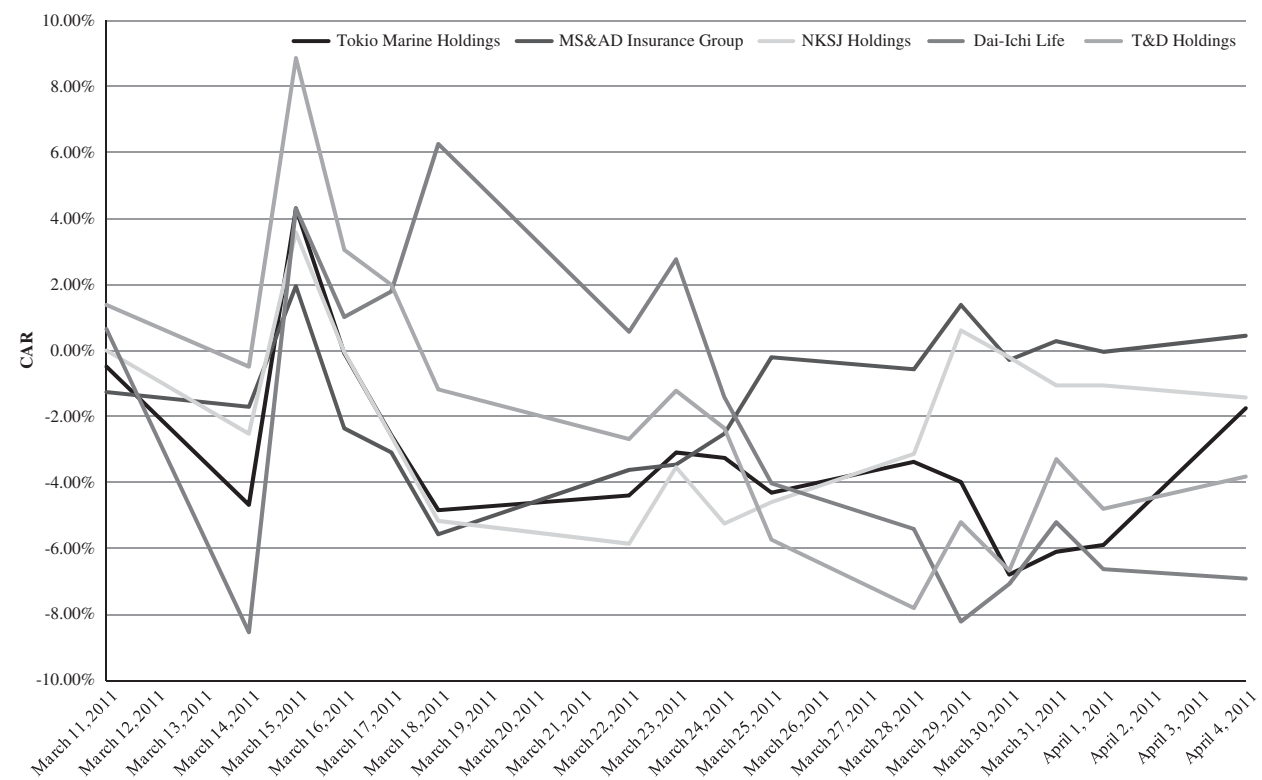

Figure 3. CARs of major Japanese insurance companies following the GEJE.

20 March. In addition, it is possible that many market participants did not understand the Japanese earthquake insurance system. As a result, the market reaction during this period may be due to the fact that many foreign and individual investors also sold non-life insurer stocks.

The CARs after the second week of the GEJE ( $t=5$ to 15 ) were 1.83 per cent $(z=2.338)$ and -7.27 per cent $(z=-8.611)$ for non-life and life insurers, respectively. It is apparent that the market rebounded strongly, which may be attributed to some clarification in whether insurers would pay their insurance claims, correcting stock prices.

Furthermore, the CARs during the full event period ( $t=0$ to 15 ) were -0.94 per cent $(z=-1.387)$ and -5.31 per cent $(z=-5.590)$ for non-life and life insurers, respectively. Throughout the entire sample period, $\mathrm{H} 1$ is confirmed, in that the variations in the CARs of life insurers were larger than those of non-life insurers. ${ }^{24}$

To examine the effect of insurers' stock prices on their financial strength, a regression analysis is further conducted as follows:

$$
S C A R_{i}^{(0,4)}=a+\text { Surplus }_{i}+\varepsilon_{t}
$$

\footnotetext{
${ }^{24}$ However, because Dai-ichi Life had the largest decline and was also Tokyo Electric Power Company's largest shareholder, it is possible this result was calculated from the loss on valuation of exiting assets instead of from the unexpectedly large insurance claims.
} 
Table 3 Cross-sectional regression results: Surplus impact on SCARs

\begin{tabular}{|c|c|c|c|c|c|}
\hline$S C A R^{(0.4)}=$ & $\begin{array}{c}-1.12 \\
(-0.97)\end{array}$ & + & $\begin{array}{c}1.11 \\
(0.21)\end{array}$ & Surplus $+\varepsilon_{t}$ & $R^{2}=0.04$ \\
\hline$S C A R^{(5.15)}=$ & $\begin{array}{c}-2.05 \\
(-1.90)\end{array}$ & + & $\begin{array}{l}11.35 \\
(2.28)\end{array}$ & Surplus $+\varepsilon_{t}$ & $R^{2}=0.84$ \\
\hline$S C A R^{(0.15)}=$ & $\begin{array}{c}-2.31 \\
(-11.71)\end{array}$ & + & $\begin{array}{c}9.85 \\
(10.79)\end{array}$ & Surplus $+\varepsilon_{t}$ & $R^{2}=0.99$ \\
\hline
\end{tabular}

Note: The $t$-statistics are in parentheses.

$$
\begin{aligned}
& \operatorname{SCAR}_{i}^{(5,15)}=c+\text { dSurplus }_{i}+\varepsilon_{t} \\
& \operatorname{SCAR}_{i}^{(0,15)}=e+\text { Surplus }_{i}+\varepsilon_{t}
\end{aligned}
$$

where $S C A R_{i}^{(t, T)}$ is the standardised CAR (SCAR) from days $t$ to $T$ of insurer $i$ and Surplus $_{i}$ is the degree of capital surplus of insurer $i$, with Surplus defined as the sum of liability reserves for earthquake insurance, catastrophic loss reserves and equity capital, which is then divided by the amount of total liability reserves. ${ }^{25} \mathrm{We}$ expect that the higher the insurer's surplus, the smaller its risk of default because it has more capital buffer.

The regression results are shown in Table 3. The surplus is not statistically significant in determining the impact on insurer stock returns in the first week $(t=0-4)$ following the GEJE. As in the analysis for Table 2, this may be the result of the strong noise caused by a rather short window. Our conjecture is demonstrated in that in both the subsequent $(t=5-15)$ and full event $(t=0-15)$ periods, surplus is significantly positive and plays an important role in the stock performance of non-life insurers. Specifically, the SCARs from days 0 to 15 are positive at the 0.1 per cent level of significance. As a result, the market returns of non-life insurers are higher for insurers with more surplus, which confirms $\mathrm{H} 2$.

\section{Conclusion}

This paper examines the market reaction of the stock prices of Japanese insurance companies, especially non-life insurers, to the GEJE. Our findings are as follows: (1) The stock prices of insurance companies decreased just after the earthquake. The spread of the downfall was less for the stock prices of non-life insurance companies than for those of life insurers. (2) The more capital buffer a non-life insurance company had, the higher its stock return.

Our results are consistent with those of Lamb, ${ }^{10}$ Cummins and Lewis, ${ }^{13}$ and Yamori and Kobayashi, ${ }^{12}$ in that the average abnormal stock returns of non-life insurance

\footnotetext{
${ }^{25}$ The liability reserves for earthquake insurance and the catastrophic loss reserves for each insurance group are calculated in the same manner as in footnote 2. Equity capital and total liability reserves are as of 31 December 2010.
} 
companies following the GEJE are significantly negative. This suggests that the GEJE provided negative signal information that the potential earthquake losses would be larger than the increase in expected insurance premiums due to increasing demand for insurance coverage. In addition, we also find that the stock prices of non-life insurers with more surplus rebound the first week after the GEJE. This finding coincides with that of Cummins and Lewis ${ }^{13}$ and supports the flight-to-quality hypothesis.

On the other hand, this paper contributes to the literature in that it finds the variations in abnormal returns of non-life insurance stock companies following the GEJE to be less than those of life insurance stock companies. This may be attributed to the fact that the GEJE has a lesser impact on non-life insurers than on life insurers. As mentioned, the net losses for Japanese non-life insurers were only 200 billion yen because of the Earthquake Insurance System on Dwelling Risks including earthquake insurance risk reserves and commercial reinsurance. Thus, this finding indicates that the Earthquake Insurance System on Dwelling Risks and the reinsurance system work well.

On the basis of the market reactions to the GEJE, it seems that the Earthquake Insurance System on Dwelling Risks in Japan has a plausible risk-pooling effect. The participation rate in Earthquake Insurance on Dwelling Risks has been rising since the GEJE. In Japan, a country that experiences frequent earthquakes, how to design and refine the insurance system and to maintain a credible insurance market to accommodate seismic hazards is a governmental necessity.

\section{Acknowledgements}

We thank two anonymous reviewers and Keiichi Morita (Mitsui Sumitomo Insurance) for their helpful comments. We accept responsibility for all errors and omissions.

\section{References}

Aiuppa, T.A., Carney, R.J. and Krueger, T.M. (1993) 'An examination of insurance stock prices following the 1989 Loma Prieta earthquake', Journal of Insurance Issues 16(1): 1-14.

Aiuppa, T.A. and Krueger, T.M. (1995) 'Insurance stock prices following the 1994 Los Angeles earthquake', Journal of Insurance Issues 18(1): 1-13.

Binder, J.J. (1985) 'On the use of the multivariate regression model in event studies', Journal of Accounting Research 23(1): 370-383.

Boehmer, E., Musumeci, J. and Poulsen, A.B. (1991) 'Event-study methodology under conditions of eventinduced variance', Journal of Financial Economics 30(2): 253-272.

Cagle, J.A.B. (1996) 'Natural disasters, insurer stock prices, and market discrimination: The case of Hurricane Hugo', Journal of Insurance Issues 19(1): 53-68.

Campbell, J.Y., Lo, A.W. and MacKinlay, A.C. (1997) The Econometrics of Financial Markets, Princeton, New Jersey: Princeton University Press.

Chen, X., Doerpinghaus, H., Lin, B.-X. and Yu, T. (2008) 'Catastrophic losses and insurer profitability: Evidence from 9/11', Journal of Risk and Insurance 75(1): 39-62.

Cummins, J.D. and Lewis, C.M. (2003) 'Catastrophic events, parameter uncertainty and the breakdown of implicit long-term contracting: The case of terrorism insurance', Journal of Risk and Uncertainty 26(2/3): $153-178$.

Fama, E.F. (1998) 'Market efficiency, long-term returns, and behavioral finance', Journal of Financial Economics 49(3): 283-306. 
Fama, E.F. and French, K.R. (1993) 'Common risk factors in the returns on stocks and bonds', Journal of Financial Economics 33(1): 3-56.

Froot, K.A. and O'Connell, P.G.J. (1999) 'The pricing of U.S. reinsurance', in K.A. Froot (eds.) The Financing of Catastrophe Risk, Chicago: University of Chicago Press.

Japan Earthquake Reinsurance (2010) 'Annual Report 2010', from http://www.nihonjishin.co.jp/disclosure/ 2010/en_disclosure.pdf, accessed 3 November 2011.

Lamb, R.P. (1995) 'An exposure-based analysis of property-liability insurer stock values around Hurricane Andrew', Journal of Risk and Insurance 62(1): 111-123.

Lamb, R.P. and Kennedy, W.F. (1997) 'Insurer stock prices and market efficiency around the Los Angeles earthquake', Journal of Insurance Issues 20(1): 10-24.

Lamm-Tennant, J. and Starks, L.T. (1993) 'Stock versus mutual ownership structures: The risk implications', Journal of Business 66(1): 29-46.

Lewis, C.M. and Murdock, K.C. (1996) 'The role of government contracts in discretionary reinsurance markets for national disasters', Journal of Risk and Insurance 63(4): 567-597.

Lyon, J.D., Barber, B.M. and Tsai, C.-L. (1999) 'Improved methods for tests of long-run stock abnormal returns', Journal of Finance 54(1): 165-201.

Mitchell, M.L. and Stafford, E. (2000) 'Managerial decisions and long-term stock price performance', Journal of Business 73(3): 287-329.

Reuters News Agency (2011) 'Insured losses from Japan quake could hit $\$ 35$ billion', from http:// www.reuters.com/article/2011/03/13/us-japan-quake-insurers-idUSTRE72B2ME20110313, accessed 27 March 2011.

Shelor, R.M., Anderson, D.C. and Cross, M.L. (1992) 'Gaining from loss: Property-liability insurer stock values in the aftermath of the 1989 California earthquake', Journal of Risk and Insurance 59(3): 476-488.

Yamori, N. and Kobayashi, T. (2002) 'Do Japanese insurers benefit from a catastrophic event? Market reactions to the 1995 Hanshin-Awaji Earthquake', Journal of the Japanese and International Economies 16(1): 92-108.

\section{Appendix A}

\section{An event study of insurance stocks following the GEJE with the MVRM approach}

A conventional event study approach assumes that abnormal returns on individual securities are independent and identically distributed across firms. Binder ${ }^{26}$ argues that there are three problems with this assumption. First, the abnormal returns are likely to differ across firms. Second, there is evidence that the variance of abnormal returns differs across firms. Finally, the abnormal returns will not be independent if the event occurs during the same calendar time period for some firms and these firms are in the same or related industries. The dependence is especially severe when both of these conditions exist for all the sample firms.

Campbell et al. ${ }^{27}$ advocate a multivariate regression model (MVRM) with dummy variables for the event date to deal with the above statistical problems. The MVRM methodology begins by estimating the abnormal returns $\gamma_{i e}$ in the individual return equations:

$$
R_{i t}=a_{i}+\beta_{i} R_{m t}+\gamma_{i e} D_{e t}+\varepsilon_{i t}
$$

\footnotetext{
${ }^{26}$ Binder (1985).

${ }^{27}$ Campbell et al. (1997).
} 
Table A1 Daily average abnormal returns following the GEJE by MVRM

\begin{tabular}{lcccr}
\hline$t$ & \multicolumn{2}{c}{$\begin{array}{c}\text { Non-life insurance company } \\
(N=3)\end{array}$} & & \multicolumn{2}{c}{$\begin{array}{c}\text { Life insurance company } \\
(N=2)\end{array}$} \\
\cline { 2 - 5 } & Mean $(\%)$ & t-test & Mean $(\%)$ & -0.745 \\
& -1.04 & $-9.890^{* *}$ & -0.21 & -1.602 \\
$(0,4)$ & 0.28 & 1.375 & -0.53 & -3.469 \\
$(5,15)$ & -0.13 & -0.864 & -0.44 & -test \\
$(0,15)$ & &
\end{tabular}

Note: The superscript $* *$ represents statistical significance at the 5 per cent level.

where $D_{e t}$ equals one during the event period and zero otherwise. When the explanatory variables in the return-generating process are the same for each of the $N$ insurers, the system of return equations

$$
\begin{aligned}
& R_{1 t}=a_{1}+\beta_{1} R_{m t}+\gamma_{1 e} D_{e t}+\varepsilon_{1 t} \\
& R_{2 t}=a_{2}+\beta_{2} R_{m t}+\gamma_{2 e} D_{e t}+\varepsilon_{2 t} \\
& \vdots \\
& R_{N t}=a_{N}+\beta_{N} R_{m t}+\gamma_{N e} D_{e t}+\varepsilon_{N t}
\end{aligned}
$$

can be estimated jointly as an MVRM.

In the section "Data and methodology", we hypothesize that the reaction of non-life insurers' stock prices is less than that of life insurers' following the GEJE. To test the hypothesis, we examine whether the following null hypothesis is rejected:

$$
H_{0}: \frac{1}{N} \sum_{i} \gamma_{i e}=0
$$

As in the section "Data and methodology", the estimation period is 200 trading days, dating back from the day before the GEJE. To match the CAR results in the section "Data and methodology", we examine three event periods: (1) 5 trading days following the GEJE $(t=0-4)$, (2) 11 trading days from 5 to 16 trading days after the GEJE $(t=5-15)$ and (3) 16 trading days following the GEJE $(t=0-15)$.

The results are shown in Table A1. As seen in Table A1, although the stock prices of non-life insurers drop much more significantly than those of life insurers following the first week of the GEJE $(t=0-4)$, the effects of the GEJE invert during the full event period $(t=0-15)$. Therefore, $\mathrm{H} 1$ is confirmed, in that the variations in the CARs of life insurers are larger than those of non-life insurers. 


\section{Appendix B}

\section{Long-term abnormal returns after the GEJE}

Heretofore, we have made the implicit assumption that investors are rational in responding to major catastrophes. Now an interesting question arises: Did investors overreact to the GEJE? If investors overreacted to the GEJE, insurance stock prices will be gradually corrected after the GEJE. Therefore, we investigate whether there are still long-run abnormal returns after the GEJE.

We implement the Fama-French ${ }^{28}$ calendar time portfolio approach as advocated by Fama ${ }^{29}$ and Mitchell and Stafford. ${ }^{30}$ Lyon et al. ${ }^{31}$ argue that the calendar time portfolio approach offers some advantages over tests that employ either cumulative or buy-and-hold abnormal returns. First, it eliminates the problem of cross-sectional dependence among sample firms because the returns on sample firms are aggregated into a single portfolio. Second, the calendar time portfolio method yields more robust test statistics in non-random samples.

For each calendar month, calculate the return on a portfolio composed of insurers (non-life vs. life) that had an event (i.e., the GEJE) within the 12-month calendar ( 1 year). The calendar time return on this portfolio is used to estimate the following regression:

$$
R_{p t}-R_{f t}=\alpha_{p}+\beta_{p}\left(R_{m t}-R_{f t}\right)+s_{p} S M B_{t}+h_{p} H M L_{t}+\varepsilon_{p t}
$$

where $R_{p t}$ is the monthly return on portfolio $p$ in the calendar month $t ; R_{f t}$ and $R_{m t}$ are the risk-free rate the value-weighted return on all TSE first and second stocks, respectively; and $S M B_{t}$ and $H M L_{t}$ are the average return on three small portfolios minus the average return on three big portfolios and the average return on two value portfolios minus the average return on two growth portfolios, respectively. We acquire these data from Kubota-Takehara's Fama-French benchmark factors in the Portfolio Master.

Table B1 Long-term abnormal returns following the GEJE

\begin{tabular}{|c|c|c|c|c|}
\hline \multirow[t]{2}{*}{12 months $(1,12)$} & \multicolumn{2}{|c|}{ Non-life insurance company } & \multicolumn{2}{|c|}{ Life insurance company } \\
\hline & $\begin{array}{c}\text { Monthly average } \\
A R(\%)\end{array}$ & t-statistic & $\begin{array}{c}\text { Monthly average } \\
A R(\%)\end{array}$ & $t$-statistic \\
\hline Equal weighted & -1.10 & -0.89 & 0.25 & 0.16 \\
\hline Value weighted & -0.85 & -0.65 & 0.40 & 0.23 \\
\hline
\end{tabular}

\footnotetext{
${ }^{28}$ Fama-French (1993).

${ }^{29}$ Fama (1998).

${ }^{30}$ Mitchell and Stafford (2000).

${ }^{31}$ Lyon et al. (1999).
} 
The intercept $\alpha_{p}$ represents the mean monthly excess return in the event period $((1,12)$ for the average excess return over the 12 months ( 1 year) after the GEJE), where month 0 is the occurrence month of the GEJE (March 2011).

The results of the calendar time approach are shown in Table B1. Table B1 reports the results of the time-series regression of equal/value-weighted non-life/life insurance portfolio returns for twelve months, starting the month after the GEJE. As seen in the table, we do not find any significant average monthly abnormal returns. Thus we conclude that insurance stock prices did not overreact to the GEJE.

\section{About the Authors}

Atsushi Takao is a professor of insurance at the Graduate School of Business Administration at Kobe University in Japan. He received his Master's and $\mathrm{PhD}$ degrees in Commerce from Kobe University. He has published many books and papers on insurance.

Takuya Yoshizawa is a general manager of the claim audit department at H.S. Insurance. He obtained his $\mathrm{PhD}$ degree in Economics from Kyushu University, Japan and LLM degree from University of Tokyo Graduate School, Japan. He was a guest professor of insurance science at Kyushu University and worked at Tokio Marine and Nichido Fire Insurance for almost 30 years. His research is focused mainly on insurance and insurance derivatives such as insurance-linked securities and finite insurance.

Shuofen Hsu is a professor of insurance in the Department of Risk Management and Insurance, National Kaohsiung First University of Science and Technology in Taiwan. She received her Master's and PhD degrees in Business Administration from Kobe University, Japan. She was Dean of the College of Finance and Banking and served as head of the Department of Risk Management and Insurance at NKFUST. Her research topics include policy and issues concerning the insurance industry and National Health Insurance.

Takashi Yamasaki is an associate professor of finance at the Graduate School of Business Administration at Kobe University in Japan. He received his Master's and $\mathrm{PhD}$ degrees in Business Administration from Kobe University. His research interests include investments, corporate finance, behavioural finance, risk management and insurance. 